\title{
СТАН ТОНКОГО КИШЕЧНИКА У ЩУРІВ ІЗ ХРОНІЧНИМ ЕНТЕРОКОЛІТОМ НА ФОНІ СТРЕПТОЗОТОЦИНОВОГО ДІАБЕТУ: ПАТОБІОХІМІЧНІ ДАНІ
}

\author{
ФН. В. Ліснянська', М. І. Марущак', Л. М. Головатюк², Ю. М. Орел'1 \\ 'ДВНЗ «Тернопільський державний медичний університет імені І. Я. Горбачевського» \\ ${ }^{2}$ Кременецька обласна гуманітарно-педагогічна академія імені Тараса Шевченка
}

РЕЗЮМЕ. Метою нашого дослідження було встановити морфологічні зміни стінки тонкої кишки тварин з цукровим діабетом, хронічним ентероколітом та їх поєднанням й обгрунтувати механізм їх розвитку.

Матеріал і методи. Дослідження проведено на 36 білих нелінійних самцях-щурах з дотриманням принципів Європейської конвенції із захисту лабораторних тварин. Цукровий діабет моделювали шляхом однократного внутрішньоочеревинного введення тваринам стрептозотоцину (Sigma Aldrich, США, в дозі 60 мг/кг маси тіла). Хронічний ентероколіт був відтворений шляхом вільного доступу тварин до 1,0% розчину карагінану у питній воді протягом 1 місяця.

Результати. При гістологічному дослідженні стінки тонкого кишечника тварин з цукровим діабетом спостерігалися істотні структурні зміни. Відмічалося вкорочення і сплощення ворсинок слизової оболонки, що свідчить про їх атрофію, в той же час крипти видовжувались, глибина їх збільшувалася.

При хронічному ентероколіті у щурів спостерігали виражені прояви запального процесу - поширену інфільтрацію слизової оболонки та підслизового шару нейтрофільними лейкоцитами з домішками лімфоцитів, гістіоцитів, еозинофілів.

Піддослідні тварини з хронічним ентероколітом на тлі цукрового діабету зазнавали комплексної патогенної дії гіперглікемії та карагінану, тому структурно-функціональні зміни тонкого кишечника у них характеризувалися більшим поліморфізмом.

Висновки. Аналіз наведених вище даних дає підстави зробити висновок, що при цукровому діабеті на фоні гіперпродукції активних форм оксигену структурні зміни стінки тонкого кишечника білих щурів характеризуються превалюванням дистрофічних процесів, які можна вважати морфологічним відображенням ентеропатії. У тварин з хронічним ентероколітом високі концентрації фактора некрозу пухлин-альфа зумовлюють морфологічну картину запалення. При хронічному ентероколіті на фоні стрептозотоцинового діабету спостерігається поєднання ознак ентеропатії та ентериту з максимальними значеннями показників активних форм оксигену і фактора некрозу пухлин-альфа, при цьому ступінь вираженості патологічних змін був вищим, ніж при ізольованому моделюванні вказаних патологічних станів.

КЛючОВІ СЛОВА: хронічний ентероколіт; стрептозотоциновий діабет; морфологічні зміни; активні форми оксигену; фактор некрозу пухлин-а; експеримент.

Вступ. Сучасні уявлення про фізіологічні механізми, які регулюють життєдіяльність клітини, диктують необхідність розгляду патологічних процесів з точки зору порушення внутрішньоклітинних молекулярних взаємодій. Згідно з даними літератури, мітохондріальна дисфункція і оксидативний стрес грають важливу роль у патогенезі хронічного ентероколіту (ХЕК) й цукрового діабету [1-4]. Порушення роботи будь-якої ділянки дихального ланцюга призводить до утворення активних форм оксигену (АФО). На сьогодні доведено, що АФО безпосередньо включаються в сигнальні шляхи клітини, значно впливаючи на всі біологічні процеси, що відбуваються в фізіологічних і патологічних умовах. Характер впливу АФО визначається насамперед їх вмістом у клітині: незначне їх підвищення призводить до гіпоксійної адаптації з допомогою HIF1a-опосередкованої регуляції, помірне збільшення їх концентрації веде до формування запальної відповіді, значне перевищення вмісту кисневих радикалів у клітині зумовлює формування пор у мембранах мітохондрій, акти- вації ATG-4 гена з подальшою аутофагією і апоптозом [5, 6]. A. Phillip West i iн. (2011) показали, що АФО індукують вироблення прозапальних цитокінів у клітинах імунної системи за допомогою активації RIG-I-подібних рецепторів, міоген-активованих протеїнкіназ й інфламасом [7]. Декілька років тому був виявлений механізм індукції синтезу АФО цитокіном TNF-a, при цьому останній чинить стимулювальну дію на $\mathrm{Ca}_{2}^{+}$-залежний шлях утворення кисневих радикалів $[7,8]$.

Мета дослідження - встановити морфологічні зміни стінки тонкої кишки тварин з цукровим діабетом, хронічним ентероколітом та їх поєднанням й обгрунтувати механізм їх розвитку.

Матеріал і методи. Дослідження проведено на 36 білих нелінійних самцях-щурах, які утримувалися на стандартному раціоні віварію Тернопільського державного медичного університету імені І. Я. Горбачевського. Під час роботи дотримувалися принципів Європейської конвенції із захисту лабораторних тварин. Піддослідних щурів поділили на три групи: 1 - тварини з цукровим 
Огляди літератури, оригінальні дослідження, погляд на проблему

діабетом, 2 - тварини з хронічним ентероколітом, 3 - тварини з цукровим діабетом і хронічним ентероколітом. Цукровий діабет (СТД) моделювали шляхом однократного внутрішньоочеревинного введення тваринам стрептозотоцину (Sigma Aldrich, США, в дозі 60 мг/кг маси тіла) [9]. Безпосередньо перед введенням стрептозотоцин розчиняли в 0,1 молярному цитратному буфері (рH 4,5); контрольній групі вводили відповідну кількість цитратного буферу. В експерименті використовували тварин з рівнем глюкози не нижче 10,8 ммоль/л через 2 тижні після введення стрептозотоцину. Хронічний ентероколіт був відтворений шляхом вільного доступу тварин до 1,0 \% розчину карагінану у питній воді протягом 1 місяця $[10,11]$. Евтаназію тварин проводили шляхом пункції серця під глибокою анестезією, відповідно до вимог Комітету по догляду за тваринами [12].

Для мікроскопічного дослідження зразки тканин тонкого кишечника фіксували 1,5 \% розчином глютарового альдегіду в 0,2 М какодилатному буфері $(\mathrm{pH} 7,2)$ при $\mathrm{t}=4^{\circ} \mathrm{C}$, протягом 1 год. Зразки промивали какодилатним буфером і додатково фіксували 2 \% розчином чотириокису осмію в тому ж буфері протягом 1 год $\left(t=4^{\circ} \mathrm{C}\right)$. Препарати відмивали від фіксаторів і зневоднювали в зростаючих концентраціях етилового спирту (50 \%, 70 \%, $90 \%$ і 100 \%). Додатково зневоднювали в 2 змінах окису пропілену і поміщали в епоксидну смолу Епон-812. Зрізи отримували за допомогою ультрамікротома УМТП-6, використовуючи алмазний ніж, контрастували 2 \% розчином уранілацетату впродовж 15 хв і додатково цитратом свинцю за Рейнольдсом [13]. Зрізи переглядали і фотографували за допомогою електронного трансмісійного мікроскопа ПЕМ-100.

Для вимірювання рівня активних форм оксигену (АФО) в суспензії лейкоцитів крові використовували дихлорфлуоресцеїну діацетат (ДХФ-ДА) («Sigma Aldrich», USA), який є барвником із заблокованою флуоресценцією [14].

Концентрацію ФНП-а в сироватці крові вивчали методом твердофазового імуноферментного аналізу з використанням наборів фірми DRG (Німеччина) [15]. Для визначення цитокінів а6сорбцію проб вимірювали на апараті «Stat Fax Plus», концентарцію ФНП-а виражали у пг/мл. ці [16].

Отримані дані піддавали статистичній оброб-

Результати й обговорення. При гістологічному дослідженні стінки тонкого кишечника тварин 1 групи спостерігали істотні структурні зміни. Відмічали вкорочення і сплощення ворсинок слизової оболонки, що свідчить про їх атрофію, в той же час крипти видовжувались, глибина їх збільшувалася. Якщо у інтактних тварин контрольної групи ad oculos висота ворсинок приблизно вдвічі перевищувала глибину крипт, то при експериментальній гіперглікемії зазначене співвідношення істотно зменшувалося, відповідно рельєф слизової оболонки згладжувався. Клітини епітелію ворсин збільшувалися в розмірах за рахунок нерівномірної вакуолізації, спостерігалася посилена базофільність їх цитоплазми, контури клітин були розмитими, війчаста облямівка подекуди не визначалася. Місцями відмічалося зміщення базально розташованих ядер епітеліоцитів у бік апікального краю клітин, що створювало картину псевдостратифікації одношарового ворсинкового епітелію. Мав місце набряк пухкої сполучної тканини власної пластинки слизової оболонки (рис. 1).

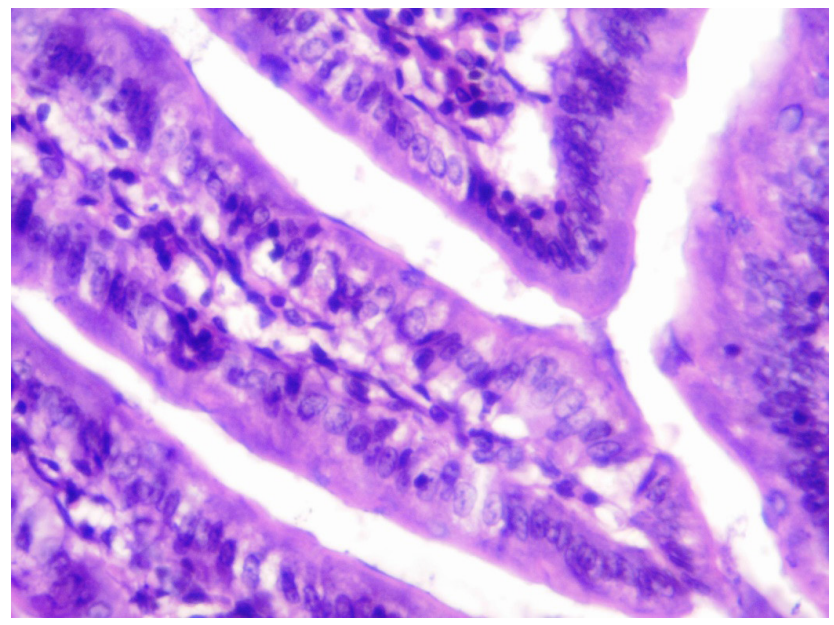

Рис. 1. Слизова оболонка тонкого кишечника білого щура при стрептозотоциновому діабеті. Вкорочення ворсинок, дистрофічні зміни епітелію, набряк сполучнотканинних елементів. Забарвлення гематоксиліном i еозином. Ок. 10, о6. 20.

Морфологічна картина патологічних змін стінки тонкого кишечника білих щурів 2 експериментальної групи істотно відрізнялася від описаних вище. Розміри ворсинок дещо збільшувалися, порівняно з контрольною групою, що було обумовлено розвитком набряку. Серед клітин поверхневого епітелію спостерігали вогнищеві дистрофічні зміни, аналогічні виявленим у 1 експериментальній групі. Місцями, переважно в апікальних частинах ворсинок, візуалізувалися осередки десквамації епітеліоцитів, також у більшості полів зору зростала кількість міжепітеліальних лімфоцитів. Спостерігали виражені прояви запального процесу - поширену інфільтрацію слизової оболонки та підслизового шару нейтрофільними лейкоцитами з домішками лімфоцитів, гістіоцитів, еозинофілів (рис. 2).

Базальна мембрана контурувалася чітко, у ній також візуалізувалися клітинні скупчення, представлені переважно лімфоцитами та нейтро- 
Огляди літератури, оригінальні дослідження, погляд на проблему

філами. У підслизовій основі відмічалися гемодинамічні розлади, набряк сполучнотканинних структур та вогнищева, переважно перивазальна, інфільтрація лімфоцитами, макрофагами, нейтрофільними лейкоцитами.

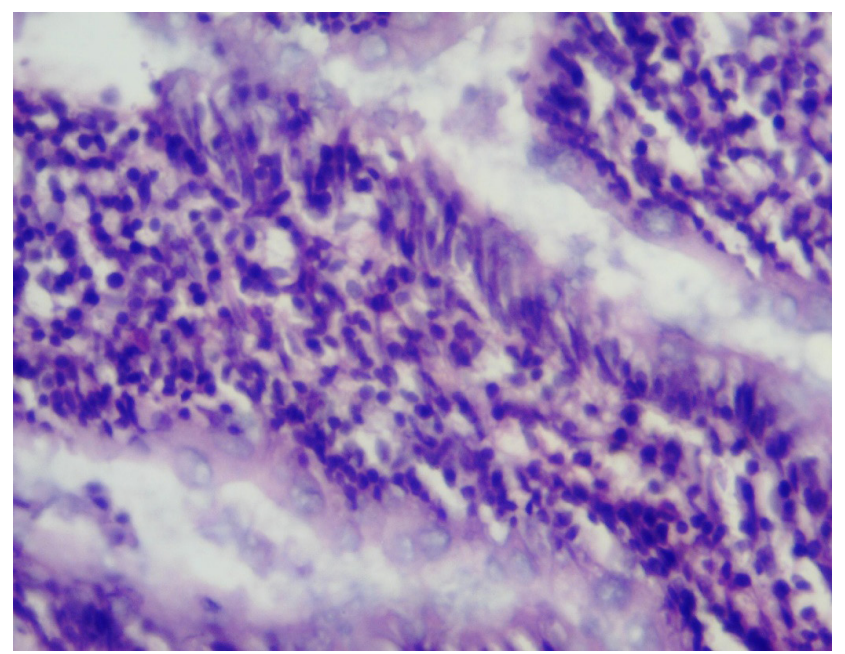

Рис. 2. Слизова оболонка тонкого кишечника білого щура при хронічному ентероколіті. Виражена дифузна запальна інфільтрація ворсинок, набряк, вогнищеві дистрофічні зміни епітелію. Забарвлення гематоксиліном і еозином. Ок. 10, об. 20.

Піддослідні тварини 3 експериментальної групи зазнавали комплексної патогенної дії гіперглікемії та карагінану, тому структурно-функціональні зміни тонкого кишечника у них характеризувалися більшим поліморфізмом (рис. 3).

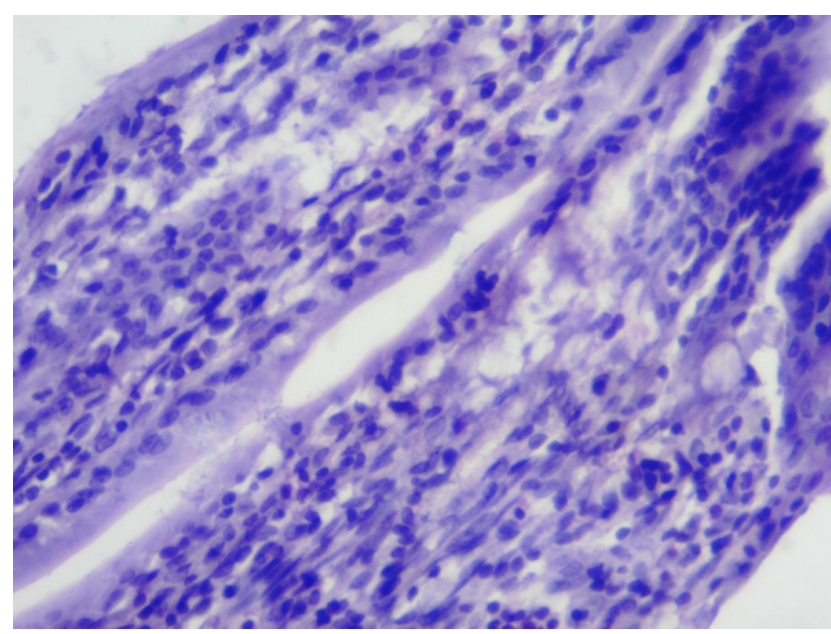

Рис. 3. Слизова оболонка тонкого кишечника білого щура при хронічному ентероколіті на тлі цукрового діабету. Дифузна запальна інфільтрація ворсинок, дистрофічні зміни епітелію, набряк і розволокнення сполучнотканинних структур. Забарвлення гематоксиліном і еозином. Ок. 10, об. 20.

Ворсинки слизової оболонки виглядали вкороченими, крипти поглиблювалися. У цитоплазмі більшості поверхневих епітеліоцитів визначалися осередки вакуолізаї у вигляді оптично порожніх ділянок, які займали частину або й усю площу клітини. Розміри уражених клітин збільшувалися. Змінювалися тинкторіальні властивості ядер: в епітелії ворсинок вони часто були гіпохромними, у криптах навпаки - базофільність їх посилювалася. Останнє можна трактувати як ознаку інтенсифікації проліферативних процесів в частині епітеліальних клітин у відповідь на пошкодження слизової оболонки. Порушувалися міжклітинні зв'язки, контури клітин чітко не простежувалися, місцями не візуалізувалася війчаста облямівка. Відмічалися осередки десквамації епітелію.

Паралельно із дистрофічними змінами також можна було спостерігати прояви ентериту. Визначалася поліморфноклітинна інфільтрація лімфоцитами, нейтрофілами, гістіоцитами і плазмоцитами слизової оболонки і підслизового шару. Базальна мембрана епітелію помірно стовщувалась за рахунок набряку, її структурні елементи розшаровувалися. На деяких зрізах запальні інфільтрати візуалізувалися також і в м'язовій оболонці кишки, тут же відмічався набряк строми, гемодинамічні розлади.

У групі тварин з СТД встановлено зростання відсотка АФО в 3,03 раза, у групі з ХЕК - в 1,98 раза, а в групі з ХЕК на фоні СТД - в 3,45 раза, порівняно з контролем. При цьому відсоток АФО був найвищий у 3 дослідній групі. Відомо, що на фоні гіперглікемії активуються різні шляхи перетворення глюкози, в результаті чого відбувається гіперпродукція АФО [17-20]. Дестабілізація ліпідного бішару, порушення трансмембранної фосфоліпідної асиметрії призводять до зміни активності мембраноз'язаних ферментів й порушень структурно-функціональної цілісності мембран. Морфологічно це проявлялося вираженими дистрофічними процесами.

При хронічному ентероколіті, за даними дослідників, порушуються функції ендотелію, які проявляються активацією процесів вільнорадикального окиснення на фоні зниження активності антиоксидантної системи, що пояснює надмірну продукцію АФО [21]. Враховуючи поширену інфільтрацію слизової оболонки та підслизового шару нейтрофільними лейкоцитами при ХЕК, можемо припустити, що джерелом АФО є нейтрофільні гранулоцити. Проте при ХЕК основним ушкоджувальним фактором $\epsilon$ гіперпродукція прозапальних цитокінів, оскільки нами встановлено, що концентрація ФНП-а у сироватці крові 2 дослідної групи підвищилася в 5,31 раза, тоді як у 1 дослідній групі - лише в 1,40 раза, порівняно 3 контролем. Це призводить до активації НАДФНоксидаз, під впливом яких відбувається міграція 
Огляди літератури, оригінальні дослідження, погляд на проблему

цитозольного комплексу до мембран та зв'язування його з цитохромом р558 з розвитком у нейтрофілах так званого кисневого спалаху [22].

Результати, отримані у 3 дослідній групі, дозволяють зробити висновок, що активація вільнорадикальних реакцій є важливим неспецифічним механізмом розвитку запалення тканин тонкої і товстої кишки на тлі цукрового діабету. Лабораторним підтвердженням поєднання морфологічних ознак при XEK на фоні СТД $є$ найвищі показники АФО в клітинах крові (у 3,45 раза більші контролю) й концентрації ФНП-а (у 8,04 раза більші контролю).

Висновок. Аналіз наведених даних дозволяє зробити висновок, що при цукровому діабеті на фоні гіперпродукції активних форм оксигену структурні зміни стінки тонкого кишечника білих щурів характеризуються превалюванням дистрофічних процесів, які можна вважати морфологічним відображенням ентеропатії. У тварин з хронічним ентероколітом високі концентрації фактора некрозу пухлин-альфа зумовлюють морфологічну картину запалення. При хронічному ентероколіті на фоні стрептозотоцинового діабету спостерігається поєднання ознак ентеропатії та ентериту з максимальними значеннями показників активних форм оксигену і фактора некрозу пухлин-альфа, при цьому ступінь вираженості патологічних змін був вищим, ніж при ізольованому моделюванні вказаних патологічних станів.

\section{ЛІТЕРАТУРА}

1. Santhanam S. Mitochondrial electron transport chain complex dysfunction in the colonic mucosa in ulcerative colitis / S. Santhanam, S. Rajamanickam, A. Motamarry // Inflamm. Bowel Dis. - 2012. - Vol. 18, № 11. P. 2158-2168.

2. Rezaie A. Oxidative stress and pathogenesis of inflammatory bowel disease: an epiphenomenon or the cause / A. Rezaie, R. D. Parker, M. Abdollahi // Dig. Dis. Sci. 2007. - Vol. 52, № 9. - P. 2015-2021.

3. Alzoghaibi M. A. Concepts of oxidative stress and antioxidant defense in Crohn's disease / M. A. Alzoghaibi // World J. Gastroenterol. - 2013. - Vol. 19, № 39. P. 6540-6547.

4. Sadovnikova I. V. Klinicheskie proyavleniya endogennoy intoksikatsii i mehanizmyi metabolicheskoy zaschityi organizma pri hronicheskih gepatitah u detey / I. V. Sadovnikova // STM. - 2011. - № 3. - P. 168-170.

5. Li X. Targeting mitochondrial reactive oxygen species as novel therapy for inflammatory diseases and cancers / X. Li, P. Fang, J. Mai // J. Hematol. Oncol. - 2013. Vol. 6. - P. 1-19.

6. Порушення енергозабезпечення тканини печінки як один із механізмів аліментарного ожиріння / О. П. Мялюк, І. М. Кліщ, В. В. Заєць, М. М. Марущак // Наукові доповіді НУБіП України. - 2016. - № 58 (Лютий). Режим доступу: http://nd.nubip.edu.ua/2016_1/5.pdf (назва з екрана).

7. West A. P. Mitochondria in innate immune responses / A. P. West, G. S. Shadel, S. Ghosh // Nat. Rev. Immunol. - 2011. - Vol. 11, № 6. - P. 389-402.

8. Dada L. A. Mitochondrial Ca2+ and ROS take center stage to orchestrate TNF-a-mediated inflammatory responses / L. A. Dada, J. I. Sznajder // J Clin Invest. - 2011. Vol. 121, № 5. - P. 1683-1685.

9. Indomethacin inhibits thymic involution in mice with streptozotocininduced diabetes / V. L. Ordodi, V. Paunescu, M. Ionac [et al.] // Artificial organs. - 2008. Vol. 32 (1). - P. 66-70.

10. Moyana T. N. Carrageenan-induced intestinal injury in the rat - a model for inflammatory bowel disease /
T. N. Moyana, J. M. Lalonde // Ann. Clin. Lab. Sci. - 1990. Vol. 20 (6). - P. 420-426.

11. Патент 97322. Україна, MPK: G09B 23/28. Спосі6 моделювання хронічного гастроентероколіту / Г. І. Губіна-Вакулюк, Н. Г. Колоусова, Т. О. Іваненко, Т. В. Горбач, В. О. Коробчанський; власник Харківський Нац. Мед. Ун-т. - № а201014510; заявл. 06.12.2010; опублік. 25.01.2012, Бюл. № 2. - 4 с.

12. Резніков О. Загальні етичні принципи екпериментів на тваринах / О. Резніков // Ендокринологія. 2003. - Вип. 8 (1). - С. 142-145.

13. Растровая электронная микроскопия и рентгеновский анализ / Дж. Гоулдстейн, Д. Ньюбери, П. Эчлин [и др.]. - М. : Мир, 1984. - Книга 2. - С. 162-317.

14. Flow cytometric studies of oxidative product formation by neutrophils: a graded response to membrane stimulation / D. A. Bass, J. W. Parce, L. R. Dechatelet [et al.] // J. Immunol. - 1983. - № 130 (4). - P. 1910-1917.

15. Сенников С. В. Методы определения цитокинов / С. В. Сенников, А. Н. Силков // Цитокины и воспаление. - 2005. - Т. 4, № 1. - С. 22-27.

16. Rebrova O. Yu. Statisticheskiy analiz meditsinskih dannyih. Primenenie paketa prikladnyih programm STATISTICA / O. Yu. Rebrova. - M. : MediaSfera, 2002. - 312 s.

17. Buse M. G. Hexosamines, insulin resistance, and the complications of diabetes: current status / M. G. Buse // Am. J. Physiol. Endocrinol. Metab. - 2006. - Vol. 290, №1. - P. 1-8.

18. Combating oxidative stress in vascular disease: NADPH oxidases as therapeutic targets / G. R. Drummond, S. Selemidis, K. K. Griendling, C. G. Sobey // Nat. Rev. Drug Discov. - 2011. - Vol. 10, № 6. - P. 453-471.

19. Giacco F. Oxidative stress and diabetic complications / F. Giacco, M. Brownlee // Circ. Res. -2010. - Vol. 107, № 9. - P. 1058-1070.

20. Дрель В. Р. Основні механізми виникнення та розвитку діабетичних ускладнень: роль нітративного стресу / В. Р. Дрель // Біологічні Студії. - 2010. - Т. 4, № 2. С. $141-158$.

21. Гріднева С. В. Роль окису азоту і процесів ліпопероксидації у розвитку хронічного невиразкового ко- 
Огляди літератури, оригінальні дослідження, погляд на проблему

літу / С. В. Гріднева // Сучасна гастроентерологія. 2003. - № 2. - С. 43-46.

22. Активні форми кисню та їх роль у метаболізмі клітин / М. І. Колісник, Г. В. Колісник, Є. Нідзюлка,
В. В. Влізло / Інститут біології тварин УААН. - Режим доступу: http://old.inenbiol.com/bt/2009/1/5.pdf (назва 3 екрана).

\section{REFERENCES}

1. Santhanam, S., Rajamanickam, S., \& Motamarry, A. (2012). Mitochondrial electron transport chain complex dysfunction in the colonic mucosa in ulcerative colitis. Inflamm. Bowel Dis., 18 (11), 2158-2168.

2. Rezaie, A., Parker, R.D., \& Abdollahi, M. (2007). Oxidative stress and pathogenesis of inflammatory bowel disease: an epiphenomenon or the cause. Dig. Dis. Sci., 52 (9), 2015-2021.

3. Alzoghaibi, M.A. (2013). Concepts of oxidative stress and antioxidant defense in Crohn's disease. World J. Gastroenterol., 19 (39), 6540-6547.

4. Sadovnikova, I.V. (2011). Klinicheskie proyavleniya endogennoy intoksikatsii i mekhanizmy metabolicheskoy zashchity organizma pri khronicheskikh gepatitakh u detey [Clinical manifestations of endogenous intoxication and mechanisms of metabolic protection of the body in chronic hepatitis in children]. STM, 3, 168-170 [in Ukrainian].

5. Li, X., Fang, P., \& Mai, J. (2013). Targeting mitochondrial reactive oxygen species as novel therapy for inflammatory diseases and cancers. J. Hematol. Oncol., 6, 1-19.

6. Mialiuk, O.P., Klishch, I.M., Zaiets, V.V., \& Marushchak, M.I. (2016). Porushennia enerhozabezpechennia tkanyny pechinky yak odyn iz mekhanizmiv alimentarnoho ozhyrinnia [Violation of energy supply of liver tissue as one of mechanisms of nutritional obesity]. Naukovi dopovidi NUBiP Ukrainy - Scientific Reports of NUBiP of Ukraine, 58. Retrieved from http:// http://nd.nubip.edu.ua/2016_1/2. pdf [in Ukrainian].

7. West, A.P., Shadel, G.S., \& Ghosh S. (2011). Mitochondria in innate immune responses. Nat. Rev. Immunol., 11 (6), 389-402.

8. Dada, L.A., \& Sznajder, J.I. (2011). Mitochondrial $\mathrm{Ca} 2+$ and ROS take center stage to orchestrate TNF-a-mediated inflammatory responses. J. Clin. Invest., 121 (5), 1683-1685.

9. Mic, A.A., Mic, F.A., Tatu, C.A., Ionac, M., Ordodi, V.L., \& Paunescu, V.L. (2008). Indomethacin inhibits thymic involution in mice with streptozotocininduced diabetes. Artificial Organs, 32 (1), 66-70.

10. Moyana, T.N., \& Lalonde, J.M. (1990). Carrageenan-induced intestinal injury in the rat - a model for inflammatory bowel disease. Ann. Clin. Lab. Sci., 20 (6), 420-426.

11. Hubina-Vakuliuk, H.I., Kolousova, N.H., Ivanenko, T.O., Horbach, T.V., Korobchanskyi, V.O. Sposib modeliuvannia khronichnoho hastroenterokolitu [Method of modeling chronic gastroenterocolitis]. Patent Ukraina, № a201014510, 2012.

12. Reznikov, O. (2003). Zahalni etychni pryntsypy eksperymentiv na tvarynakh [General ethical principles of experiments on animals]. Endokrynolohiia - Endocrinology, 8,(1), 142-145 [in Ukrainian].

13. Gouldsteyn, Dzh., Nyuberi, D., Echlin, P., Dzhoy, D., Fiori, Ch., \& Lifshin, E. (1984). Rastrovaya elektronnaya mikroskopiya i rentgenovskiy analiz [Raster electron microscopy and X-ray analysis]. Moscow: Mir [in Ukrainian].

14. Bass, D.A., Parce, J.W., Dechatelet, L.R., Szejda, P., Seeds, M.C., \& Thomas, M. (1983). Flow cytometric studies of oxidative product formation by neutrophils: a graded response to membrane stimulation. J. Immunol., 130 (4), 19101917.

15. Sennikov, S.V., \& Silkov, A.N. (2005). Metody opredeleniya tsitokinov [Methods for the determination of cytokines]. Tsitokiny $i$ vospalenie - Cytokines and Inflammation, 4 (1), 22-27 [in Ukrainian].

16. Rebrova, O.Yu. (2002). Statisticheskiy analiz meditsinskikh dannykh. Primenenie paketa prikladnykh programm STATISTICA [Statistical analysis of medical data. Application of software package STATISTICA]. Moscow: MediaSfera [in Russian].

17. Buse, M.G. (2006). Hexosamines, insulin resistance, and the complications of diabetes: current status. Am. J. Physiol. Endocrinol. Metab., 290 (1), 1-8.

18. Drummond, G.R., Selemidis, S., Griendling, K.K, \& Sobey, C.G. (2011). Combating oxidative stress in vascular disease: NADPH oxidases as therapeutic targets. Nat. Rev. Drug Discov., 10, 6, 453-471.

19. Giacco, F., \& Brownlee, M. (2010). Oxidative stress and diabetic complications. Circ. Res, 107, 9, 10581070.

20. Drel, V.R. (2010). Osnovni mekhanizmy vynyknennia ta rozvytku diabetychnykh uskladnen: rol nitratyvnoho stresu [The main mechanisms of the emergence and development of diabetic complications: the role of nitrate stress]. Biolohichni Studii - Biological Studios, 4 (2), 141-158 [in Ukrainian].

21. Hridneva, S.V. (2003). Rol okysu azotu i protsesiv lipoperoksydatsii u rozvytku khronichnoho nevyrazkovoho kolitu [The role of nitric oxide and lipoperoxidation processes in the development of chronic non-ulcer colitis]. Suchasna hastroenterolohiia - Modern Gastroenterology, 2, 43-46 [in Ukrainian].

22. Kolisnyk, M.I., Kolisnyk, H.V., Nidziulka, Ye., \& Vlizlo, V.V. Aktyvni formy kysniu ta yikh rol u metabolizmi klityn [Active forms of oxygen and their role in cell metabolism]. Instytut biolohii tvaryn UAAN - Institute of Animal Biology of UAAS. Available at: http://old.inenbiol.com/ bt/2009/1/5.pdf [in Ukrainian]. 


\title{
Огляди літератури, оригінальні дослідження, погляд на проблему \\ СОСТОЯНИЕ ТОНКОГО КИШЕЧНИКА У КРЫС С ХРОНИЧЕСКИМ ЭНТЕРОКОЛИТОМ НА ФОНЕ СТРЕПТОЗОТОЦИНОВОГО ДИАБЕТА: ПАТОБИОХИМИЧЕСКИЕ ДАННЫЕ
}

\section{ОН. В. Лиснянская ${ }^{1}$, М. И. Марущак'1, Л. М. Головатюк², Ю. Н. Орел'1}

${ }^{1}$ Тернопольский государственный медицинский университет имени И. Я. Горбачевского

${ }^{2}$ Кременецкая областная гуманитарно-педагогическая академия имени Тараса Шевченко

РЕЗЮМЕ. Целью нашего исследования было установить морфологические изменения стенки тонкой кишки животных с сахарным диабетом, хроническим энтероколитом и их сочетанием и обосновать механизм их развития.

Материал и методы. Исследование проведено на 36 белых нелинейных самцах-крысах с соблюдением принципов Европейской конвенции по защите лабораторных животных. Сахарный диабет моделировали путем однократного внутрибрюшинного введения животным стрептозотоцина (Sigma Aldrich, США, в дозе 60 мг/кг массы тела). Хронический энтероколит был воссоздан путем свободного доступа животных к 1,0 \% водному раствору каррагинана в течение 1 месяца.

Результаты. При гистологическом исследовании стенки тонкого кишечника животных с сахарным диабетом наблюдались существенные структурные изменения. Отмечалось укорочение и уплощение ворсинок слизистой оболочки, что свидетельствует об их атрофии, в то же время крипты удлинялись, глубина их увеличивалась.

При хроническом энтероколите у крыс наблюдались выраженные проявления воспалительного процесса распространенная инфильтрация слизистой оболочки и подслизистого слоя нейтрофильными лейкоцитами с примесью лимфоцитов, гистиоцитов, эозинофилов.

Подопытные животные с хроническим энтероколитом на фоне сахарного диабета испытывали комплексное патогенное действие гипергликемии и каррагинана, поэтому структурно-функциональные изменения тонкой кишки у них характеризовались большим полиморфизмом.

Выводы. Анализ приведенных выше данных позволяет сделать вывод, что при сахарном диабете на фоне гиперпродукции активных форм кислорода структурные изменения стенки тонкого кишечника белых крыс характеризуются преобладанием дистрофических процессов, которые можно считать морфологическим отражением энтеропатии. У животных с хроническим энтероколитом высокие концентрации фактора некроза опухолей-альфа обусловливают морфологическую картину воспаления. При хроническом энтероколите на фоне стрептозотоцинового диабета наблюдается сочетание признаков энтеропатии и энтерита с максимальными значениями показателей активных форм кислорода и фактора некроза опухолей-альфа, при этом степень выраженности патологических изменений была выше, чем при изолированном моделировании указанных патологических состояний.

КЛЮЧЕВЫЕ СЛОВА: Хронический энтероколит; стрептозотоциновый диабет; морфологические изменения, активные формы кислорода; фактор некроза опухолей-альфа; експеримент.

\section{STATE OF THE SMALL INTESTINE AT CHRONIC ENTEROCOLITIS COMBINED WITH STREPTOZOTOCIN-INDUCED DIABETES IN RATS: PATHOBIOCHEMICAL DATA}

\author{
@N. V. Lisnianska', M. I. Marushchak', L. M. Holovatiuk' ${ }^{2}$ Yu. M. Orel' \\ 1. Horbachevsky Ternopil State Medical University \\ ${ }^{2}$ Taras Shevchenko Kremenets Regional Humanitarian Pedagogical Academy
}

SUMMARY. The aim of our study was to establish the morphological changes of the small intestine wall of animals with diabetes mellitus, chronic enterocolitis and their combination, and to justify the mechanism of their development.

Materials and Methods. The study was conducted on 48 white non-linear male rats in accordance with the principles of the European Convention for the Protection of Laboratories. Diabetes mellitus was modeled by a single intraperitoneal administration of streptozotocin to animals aged 2 months, (Sigma Aldrich, USA, at a dose of $60 \mathrm{mg} / \mathrm{kg}$ of body weight). Chronic enterocolitis was induced by a free access of animals to $1.0 \%$ solution of carrageenan in drinking water for 1 month.

Results. In the histological examination of the small intestine walls of animals with diabetes were observed significant structural changes. It was noted shortening and flattening the villi of the mucous membrane, indicating their atrophy, while crypt elongation, their depth increased.

There were marked manifestations of the inflammatory process in chronic enterocolitis in rats - widespread infiltration of the mucous membrane and submucosal layer by neutrophilic leukocytes with admixture of lymphocytes, histiocytes, eosinophils.

Experimental animals with chronic enterocolitis on the background of diabetes suffered from a complex pathogenic effect of hyperglycemia and carrageenan, therefore, structural-functional changes of the small intestine were characterized by a large polymorphism.

Conclusions. The analysis of the data gives possibility to conclude that in diabetes mellitus against hyperproduction 
Огляди літератури, оригінальні дослідження, погляд на проблему

of free oxygen radicals, structural changes in the small intestine wall of white rats are characterized by the prevalence of dystrophic processes, which can be considered like morphological reflection of enteropathy. In animals with chronic enterocolitis, high concentrations of the tumor necrosis factor determine the morphological picture of inflammation. In chronic enterocolitis combined with diabetes, there is a combination of signs of enteropathy and enteritis with the maximum values of the indicators of free oxygen radicals and tumor necrosis factor alpha and the degree of severity of pathological changes was higher than in the isolated models of these pathological states.

KEY WORDS: chronic enterocolitis; streptozotocin diabetes; morphological changes; free oxygen radicals; tumor necrosis factor alpha; experiment.

Отримано 10.08.2017 